\title{
The Correlation Between EFL College Students' Self- Efficacy and Their Listening Anxiety at Intermediate Listening Class
}

\author{
Leni Marlina $^{1 *}$, Aryuliva Adnan ${ }^{2}$, Edi Trisno ${ }^{3}$, and Faidhurrahmat ${ }^{4}$ \\ ${ }^{1234}$ English Department, FBS Universitas Negeri Padang, Padang, Sumatra Barat 25131, Indonesia \\ *Corresponding author. Email: lenimarlina@fbs.unp.ac.id
}

\begin{abstract}
Self-efficacy is important for improving emotional states and to correct faulty self-beliefs and habits of thinking, academic skills and self-regulatory practices improvement. Anxiety prevents EFL learners in improving their language learning skills. This research inspect the self-efficacy and whether it is in correlation with their listening anxiety experienced by EFL college learners. The data of the research was obtained from all of the 2019 learners and it was collected by using two instruments: Foreign Language Listening Anxiety Questionnaire (FLLAQ) and Listening Self-efficacy Beliefs Questionnaire (LSBQ). This research was conducted by using random sampling. The result showed there was a positive correlation between EFL learners' listening self-efficacy and their listening anxiety $(r=0.364)$ and average learners' listening anxiety and self-efficacy level stand in the medium level.
\end{abstract}

Keywords: self-efficacy, listening anxiety, intermediate listening

\section{INTRODUCTION}

Due to the urgency of using English as second language many nonnative-speaking country especially in the South East Asia country put and improve their language learning program in the curriculum. Southeast Asia has many multicultural backgrounds and Multilanguage. In Indonesia for instance, there are over three hundred different native languages which makes a challenge for the Indonesian government to construct a better English language learning program [1]. The purpose of this program usually to overcome the problem of many English Foreign Language (EFL) learners faced especially in the Asia continent with their Asian learning culture. One of the examples of the obstacle that may EFL learners face in reaching the listening competency is the listening anxiety. Listening anxiety prevent the learners form developing their confidence and developing the skill in the language classroom. Many researchers found that listening anxiety have a bad impact to EFL learners. Golchi [2] found that listening anxiety decreases their listening strategy use which lead to decrease of the listening improvement. Bekleyen [3] also found that listening anxiety correlated negatively with EFL learners' achievement. Serraj \& Noordin [4] also stated that listening anxiety correlated negatively with the listening comprehension. According to the result of the several researches above, the students with a higher level of anxiety will lead into the decreasing of performance in listening activity.

Another aspect that affects the listening competency of the EFL learners is self-efficacy. Selfefficacy is one of the social cognitive theory that brought by Bandura [5]. Social cognitive theory is important for improving their emotional states and to correct their faulty self-beliefs and habits of thinking (personal factors), improve their academic skills and self-regulatory practices (behaviour). Self-efficacy is also important for EFL learners in achieving their achievement in language learning. According to Mills [6] self-efficacy has been the researchers' concern on this past 30 years. Students with high self-efficacy to perform academic tasks tend to exhibit lower levels of anxiety, display increased persistence when faced with obstacles, exert greater effort, show more flexible learning strategy use, and display higher levels of intrinsic interest in academic tasks and the low selfefficacy student tend to do the opposite [7].

Coping with the discussion above, it can be assumed that learners with higher level of listening anxiety tend to have similar symptoms with the learners with lower level of self-efficacy and also listening anxiety and self-efficacy are both derived term from the social cognitive theory. Due to the assumption above, this study intends to investigate the correlation between self-efficacy and listening anxiety experienced by EFL college students at English Department, Universitas Negeri Padang. 
A number of studies in these past 5 years have investigated the influence of listening self-efficacy to EFL learners [8]; [9];[10];[11];[12];[13];[14]. The studies found there is a significant positive correlation between self-efficacy and learner achievement in the language classroom. This is indicating that self-efficacy is one of the indicators for a better learning achievement in the language learning field. On the other hand, many researchers investigated listening anxiety [15];[16];[17];[18] found listening anxiety is correlated negatively with the students' performance. Even though there are many studies conducted in listening anxiety and listening self-efficacy, little research has been conducted to explore the correlation between listening anxiety and the listening self-efficacy in the university language learning program. The results of this research are expected to contribute to both theoretical and practical English language learning. Based on the preliminary data by observing the learners in listening class at English Department, Universitas Negeri Padang., many learners afraid of participating on raising a hand on the class and they tend to lose focus in performing the listening task. Therefore, it stimulated this study to investigate the correlation between EFL learners' listening anxiety and listening self-efficacy in listening class at English Department, Universitas Negeri Padang.

\subsection{Listening Anxiety}

Anxiety is a feeling of tension, apprehension, nervousness, and worry associated with an arousal of the autonomic nervous system [19]. According to Zeidner \& Matthews [20] anxiety is also often futureoriented and usually it accompanies concerns over possible disasters that the person anticipated. He also stated that a person who experienced anxiety response to it usually feels uncertain how to act and overcome it. Anxiety is a complex multidimensional construct that consist of cognitive, affective, somatic, and behavioral reactions [20]. On the cognitive aspect, the learner may feel the disturbance of thinking which lead into changing of the cognitive process such as heightened awareness of the threat, and a focusing of attention on possible dangers. The affective aspect related to the negative emotion that the learners experienced such as feeling tense, nervous, and jittery. The somatic aspect refers to the physical response of the learner such as racing heart and sweaty palms. The last reaction that learners may feel is in the behavioral aspect, the learner may raise certain habit such as fidgeting. Anxiety also experienced in many forms or contexts. Knowing the general conceptualization of anxiety will be helpful to understand the context-focused form of anxiety. One of the example form of anxiety is the foreign language anxiety which is an anxiety associated and usually happen in the foreign language class environment and the anxiety that happen in particular language skill for example listening is called listening anxiety [21].

Listening anxiety is one of the language anxiety categories. Language anxiety is a distinct complex of self-perceptions, beliefs, feelings, and behaviors related to classroom language learning arising from the uniqueness of the language learning process [22] Language anxiety that occurred in foreign language learning context is a foreign language anxiety and it is "a fear or apprehension occurring when a learner is expected to perform in a second or foreign language [22]. "Listening anxiety is mainly associated with learners' language competence, the characteristics of language input, and the nature of spoken language, which is ephemeral and out of listeners' control" [23]. In other word listening anxiety is an obstacle that happens to the EFL learners in listening activity. According to Vandergrift \& Goh [24] Anxiety is one of the learners' affective factors besides self-efficacy and motivation that influence a listening success. He stated that this factor will affect listening success in both macro level (e.g., overall self-regulation of listening by the listener) and micro level (e.g., the quality and quantity of processing resources available for and allocated to the task). Therefore, anxiety plays an important role in listening success.

Chang [23] in his study found several indicators of listening anxiety of the learners; the first is low confidence of comprehending spoken English. Many learners feel doubt with themselves and anxious that the spoken English speech was fast. They also felt more tense, afraid of eye contact with the teacher, and afraid of being laughed by their peers and this resulted with the learners didn't want to volunteer an answer. The second is taking English listening courses as a requirement. The learners considerate listening was an important skill, but their low listening proficiency caused them to feel anxious when the course was required. The last is worrying about test difficulty. There are several aspect of test that provoke the anxiety in learners such as test content, speech speed, and type of the test for example the learners felt more relax with multiple choices.

language anxiety has three identified elements of which are communication apprehension, test anxiety, and fear of negative evaluation [25]. Communication apprehension is related with the fear or anxiety faced by an individual when carrying conversation. Learners with communication apprehension are shy about communicating with others and have difficulty speaking in public and listening to spoken messages. Therefore it will develop language anxiety since language class 
require them to communicate each other. Test anxiety is related with the language anxiety because it developed by the unrealistic expectation of the learners toward the language achievement. Usually the low or even a moderate score on the test will arouse the anxiety within the learners because they see it as failure or see themselves as incompetent learners. In language classes, evaluation is not limited to a test-taking situation. It may occur in any evaluative situation, such as group discussions or speaking in front of the classroom. Students who fear negative evaluations from others may also develop language anxiety. There are three types of anxiety: "state anxiety, trait anxiety and situationspecific anxiety" [26]. Foreign language anxiety is categorized as situation-specific anxiety because the anxiety only appears on the certain context or situation [27].

In completion, listening anxiety is a serious problem faced by the learners since it affected their listening success and their behaviour toward the language class. In order to minimize it learners and lectures should work together in solving this problem.

\subsection{Listening Self-Efficacy}

Bandura [5] define self-efficacy as people's beliefs about their capabilities to produce designated levels of performance that exercise influence over events that affect their lives and it determine how people feel, think, motivate themselves and behave. He stated that there are four self-efficacy sources which are mastery experiences, vicarious experiences, social persuasion and emotional condition.

Mastery experiences are the accomplishments that the students did in the past. Bandura [5] believe that the sense of the past accomplishment will boost the student to be more successful in the future. Vicarious experiences are the accumulation of experienced gained by the observation of social models. This activity will generate the learners to feel that they are able to accomplish the difficult tasks by portraying themselves to the social models (teachers, friends, experts, etc.) that they observed. Social persuasion will also generate the same feeling by using verbal persuasion. Praising the learners for their work is one of the examples that usually teachers do. Emotional condition or emotional arousal is related with learners psychological condition. People with higher self-efficacy tend to alter their negative emotion to facilitate their self-belief of doing tasks.

Demir [28] stated that positive self-perception and belief in success can affect students' participation in classroom activities and help them avoid deciding that the activities are beyond their abilities. Tabrizi \& Saeidi [12] suggested that teacher's sense of self efficacy should be involved in developing the learners positive attitude toward learning experience and it will also boost the learners' self-efficacy. According to Kassem [10] possessing enhanced listening comprehension and higher self-efficacy helps individual academic study. In the line with this Rahimi \& Abedi [29] stated that success in language learning involve self-efficacy because learners who have higher self-efficacy have more control over the process of listening.

In completion, self-efficacy is the learner belief or personal judgement toward the problem that they want to execute. The positive or high self-efficacy have a greater impact on get a better achievement on the contrary negative or low self-efficacy have a bad impact for student in achieving their goals. Higher self-efficacy means the learner have the confident in taking the challenges or obstacles that they confronted. In other word, recognizing their self-efficacy level will helps the learners in improving their listening skill in order to reach their listening competency.

\subsection{Research Question}

The problem of this research is formulated in this following question:

1. What is the level of listening anxiety of learners who take Intermediate Listening class at English department of Universitas Negeri Padang ?

2. What is the level of listening self-efficacy of learners who take Intermediate Listening class at English department of Universitas Negeri Padang ?

3. What is the correlation between listening anxiety and Listening Efficacy of learners who take Intermediate Listening class at English department of Universitas Negeri Padang?

\section{METHOD}

The type of this research is correlational where the researcher will use quantitative data analysis. The type of data is measured using numbers and values.

\subsection{Participants}

The population of this research is the second year students of English Department at Universitas Negeri Padang who are taking Intermediate Listening class. The researcher will use Simple Random Sampling where there is a withdrawal from a population in a certain way so that each member of the population has the same opportunity to be selected. Therefore, from the total population, the researcher randomly took $10 \%$ learners from all classes to be participants. "A good maximum sample size is usually around $10 \%$ of the population, as long as this does not exceed 1000" [30]. There were six classes in this population. 


\subsection{Instrumentation}

The researcher will collect the data by using two questionnaires: Foreign Language Listening Anxiety Questionnaire (FLLAQ) and Listening Self-efficacy Beliefs Questionnaire (LSBQ). The LSBQ is adapted from Tabrizi \& Saeidi, [12] and the FLLAQ is adopted from Marzec-Stawiarska [31]. Both questionnaires use Likert Scale items which popular to measure one concept. The adoption and adaptation held to adjust the research needs based on the research question and purpose in the chapter 1 . The LSBQ is used to asses to measure the participants' self-efficacy in listening comprehension and FLLAQ is used to investigate sources and symptoms of foreign language listening anxiety. FLLAQ's Cronbach alpha score is .954 which fall into the very high reliability category on other hand the LSBQ's Cronbach alpha score is .540 which fall into moderate reliability category.

\section{RESULT AND DISCUSSION}

The researchers provided the descriptive statistics of the participants listening anxiety level, and listening self-efficacy level which can be seen bellow.

\subsection{Listening anxiety analysis}

The data is gathered from FLLAQ which already filled by the respondents and it analysed using SPSS 16.0 version. The results of the analyzed data in this research will be showed on this following table

Table 1 Descriptive Statistics of Listening Anxiety

\begin{tabular}{|c|c|c|c|c|c|}
\hline & N & Minimum & Maximum & Mean & Std. Deviation \\
\hline Listening Anxiety & 60 & 120 & 244 & 174.80 & 27.401 \\
\hline
\end{tabular}

Table 1 shows the descriptive statistics of listening anxiety of the learners. Questionnaire's scores range start from 120 to 244 . The mean score for listening anxiety was 174.80 and the standard deviation was 27.401 .

To find out the range of anxiety level the researcher use the three categorization formula which can be seen on the table below.
Table 2 Range of Anxiety Level

\begin{tabular}{|l|l|l|}
\hline Categorization & Frequency & Percentage \\
\hline Low & 10 & $16.7 \%$ \\
\hline Medium & 40 & $66.7 \%$ \\
\hline High & 10 & $16.7 \%$ \\
\hline Total & $\mathbf{6 0}$ & $\mathbf{1 0 0 \%}$ \\
\hline
\end{tabular}

\subsection{Listening self-efficacy}

The data is gathered from LSBQ which already filled by the respondents and it analysed using SPSS 16.0 version. The results of the analyzed data in this research will be showed on this following table

Table 3 Descriptive Statistics of Listening Self-Efficacy

\begin{tabular}{|c|c|c|c|c|c|}
\hline & N & Minimum & Maximum & Mean & Std. Deviation \\
\hline Listening Self-Efficacy & 60 & 29 & 50 & 35.77 & 3.572 \\
\hline
\end{tabular}

Table 3 show questionnaire's scores range start from a 29 to 50 . The mean score for listening selfefficacy scores was 35.77 and the standard deviation was 3.572. To find out the range of self-efficacy level the researcher use the three categorization formula which can be seen on the table below.

Table 4 Range of Self-efficacy Level

\begin{tabular}{|l|l|l|}
\hline Categorization & Frequency & Percentage \\
\hline Low & 13 & $21.7 \%$ \\
\hline Medium & 40 & $66.7 \%$ \\
\hline High & 7 & $11.7 \%$ \\
\hline Total & $\mathbf{6 0}$ & $\mathbf{1 0 0 \%}$ \\
\hline
\end{tabular}

From the table above, the data show that 13 learners $(21.5 \%)$ fall into low category. The medium category is filled with 40 learners (67\%) and the high category is filled with 7 learners $(11.5 \%)$.

\subsection{The correlation between listening anxiety and listening self-efficacy analysis Listening anxiety analysis \\ To analyse the correlation between listening} anxiety and listening self-efficacy of the learners in Universitas Negeri Padang, the researcher had use the SPSS version to compile both data. The result can be seen in the table below. 
Table 5 Correlation between Listening Anxiety and Listening Self-Efficacy

\begin{tabular}{|c|c|c|c|}
\hline & & Listening Anxiety & Listening Self-efficacy \\
\hline \multirow{3}{*}{ Listening Anxiety } & Pearson Correlation & 1 & $.364^{* *}$ \\
\hline & Sig. (2-tailed) & & .004 \\
\hline & $\mathrm{N}$ & 60 & 60 \\
\hline \multirow{3}{*}{ Listening Self-efficacy } & Pearson Correlation & $.364^{* * *}$ & 1 \\
\hline & Sig. (2-tailed) & .004 & \\
\hline & $\mathrm{N}$ & 60 & 60 \\
\hline
\end{tabular}

The table above shows that the correlation coefficient (r) is 0.364 and the probability of significant Sig. (2-tailed) ( $\rho$ ) is 0.004 . It can be described that there is a positive correlation between listening anxiety $(\mathrm{X})$ and listening self-efficacy(Y).

\subsection{Discussion}

The findings analysis already shows the level of listening anxiety, listening self-efficacy and the correlation of both variables. First of all, the researcher would like to discuss about the anxiety level among the learners, the data show that the medium listening anxiety category frequency is $67 \%$ participant and both low listening anxiety category and high listening anxiety category have the same frequency which is $16,5 \%$ participants. It means that the listening anxiety of learners in English department is on average. Next, the listening self-efficacy level data show that $21.5 \%$ participants is in low category, 67\% participants is in medium category and the high category is filled with $11.5 \%$ participants. On the listening self-efficacy level, the majority of the participants also fall into medium category. Therefore the level of listening anxiety and the level of listening self-efficacy in English department, Universitas Negeri Padang is average. Moreover, the correlation result between listening anxiety and listening self-efficacy come out to be $r=0.365$ and the significance is $\rho=0.004$. Therefore, it can be interpreted that there is a significant positive correlation between variables $\mathrm{X}$ and $\mathrm{Y}$. However, the correlation is in low level which mean when the level of listening anxiety of the learner increasing, the level of listening self-efficacy will also increasing but slightly in other word it is not significantly increasing, vice versa. According to Ehrman (1996)[32] in his book stated that motivation, self-efficacy and anxiety are closely linked because when the performance disappointment of learner happen, it could lead to reduced self-efficacy, reduced motivation and increased anxiety. However, the result show otherwise, when the anxiety increase, the selfefficacy also increasing, vice versa.

Referring to the purpose of this study, the first question of the research is already answered where the majority of the level of listening anxiety who take
Intermediate Listening class at English department of Universitas Negeri Padang fall into medium category. For the second question, of the research is also already answered where the majority of the level of listening self-efficacy who take Intermediate Listening class at English department of Universitas Negeri Padang fall into medium category. For the third question, the correlation of both variable $\mathrm{X}$ and $\mathrm{Y}$ is a positive correlation.

\section{CONCLUSION}

According to the result finding, the learners' listening anxiety and learners' listening self-efficacy have a significant positive correlation. The category of the correlation is low correlation category. It implies that when the learners raise their anxiety in the listening class they will also increase their self-belief or selfefficacy too vice versa. The level of average both learners' anxiety and learners' self-efficacy is on medium level.

Based on the result of the study, the researcher provides some suggestions as following:

1. Lecturer should pay more attention to the selfefficacy and listening anxiety of the learners.

2. Learners should increase their self-belief in order to facilitate their learning process since the learners with high self-efficacy help them to be more confidence toward the goal of the learning

3. Learners should also aware with their anxiety when doing the listening activity because it will be a burden and obstacle for them if it not taken seriously.

4. For future researchers, this research can be used as one of the references in conducting their listening anxiety or self-efficacy studies.

This study has a limitation that should be noted. The preliminary data was obtained through interview with the lecturer which has a potential of self-reported data that could lead into a bias. 


\section{REFERENCES}

[1] D. P. Sandjaja, Indonesian. Retrieved from https://asian.washington.edu/fields/indonesian, 2020.

[2] M. M. Golchi, Listening Anxiety and Its Relationship with Listening Strategy Use and Listening Comprehension among Iranian IELTS Learners, 2012. DOI: https:// doi.org/10.5539/ijel.v2n4p115.

[3] N. Bekleyen, Helping teachers become better English students: Causes, effects, and coping strategies for foreign language listening anxiety, 2009.

DOI: https://doi.org/10.1016/j.system.2009.09.010.

[4] S. Serraj, N. Noordin, Relationship among Iranian EFL Students' Foreign Language Anxiety , Foreign Language Listening Anxiety and Their Listening Comprehension, 2013, pp. 1-12. DOI: https://doi.org/10.5539/elt.v6n5p1.

[5] A. Bandura, Self-Efficacy, 1998, pp. 1-65.

[6] N. Mills, Self-Efficacy in Second Language Acquisition, 2009, pp. 6-22.

[7] F. Pajares, D. H. Schunk, Self-Beliefs and School Success: Self-Efficacy, Self-Concept, and School Achievement, 2001, pp. 239-266.

[8] M. Davoudi, M. Chavosh, The Relationship between Multiple Intelligences and Listening Self-Efficacy among Iranian EFL Learners, 2016, pp. 199-212. DOI: https://doi.org/10.5539/elt.v9n6p199

[9] G. Genç, Exploring EFL Learners ' Perceived Selfefficacy and Beliefs on English Language Learning on English Language Learning, 2016.

[10] H. M. Kassem, The Relationship between Listening Strategies Used by Egyptian EFL College Sophomores and Their Listening Comprehension and Self-efficacy, 2015.2 DOI: https://doi.org/10.5539/elt.v8n2p153

[11] P. Kitikanan, P. Sasimonton, The Relationship between English Self - efficacy and English Learning Achievement of L2 Thai Learners, 2017, pp. 149-164.

[12] H. M. Tabrizi, M. Saeidi, The Relationship among Iranian EFL Learners ' Self-efficacy, Autonomy and Listening Comprehension Ability, 2015. DOI: https://doi.org/10.5539/elt.v8n12p158

[13] Y. Todaka, European Journal of English Language Teaching Self-Efficacy of English Listening Skills in Japanese College EFL Learners, 2017, pp. 93120. DOI: https://doi.org/10.5281/zenodo.321540

[14] P. Yang, In-Class Online Discussion Activities to Enhance EFL Learners' English Self -Efficacy and Language Learning Strategies, 2016, pp. 115-129.

[15] M. R Dalman, The Relationship between Listening Anxiety, Listening Comprehension Strategies , and Listening Performance among Iranian EFL University Students, 2016, pp. 241-252.

[16] H. Li, A Study of EFL Listening Anxiety in a Test Setting, 2015 pp. 106-114. DOI: https://doi.org/10.5539/ijel.v5n2p106

[17] Z. Lili, Influence of Anxiety on English Listening Comprehension: An Investigation Based on the Freshmen of English Majors, 2015 pp. 40-47. DOI: https://doi.org/10.3968/7952

[18] M. Liu, J. Thondhlana, A Study of Chinese University EFL Learners ' Foreign Language Listening Anxiety, Listening Strategy Use and Academic Listening Performance, Indonesian Journal of English Language Teaching, 2015, pp. $30-47$.

[19] C. D. Spielberger, G. Jacobs, R. Crane, S. Russell, L, Westberry, L. Barker, E, Marks, State-trait personality inventory (STPI), Preliminary manual, SAGE Publications, 1979.

[20] M. Zeidner, G. Matthews, Anxiety 101, Springer Publishing Company LLC, 2011.

[21] Z. Král'ová, Foreign Language Anxiety, 2019.

[22] D. He, Foreign Language Learning Anxiety in China, Springer, 2018.

[23] A. C. Chang, Sources of Listening Anxiety in Learning English as A Foreign Language, 2008, pp. 21-34.

[24] L, Vandergrift, C. C. M. Goh, Teaching and Learning Second Language Listening, Routledge, 2012.

[25] N. Ni Hlaing, W. Yan Min Oo, , An Investigation into Classroom and Language Skills' Anxiety among Myanmar EFL Students, 2017, pp. 1-23.

[26] Y. Shi, Listening Anxiety in English Learning Among International Students in A Secondary School in the UK, 2017.

[27] $\mathrm{K}$. Wu, The Relationship between Language Learners' Anxiety and Learning Strategy in the CLT Classrooms, 2007, pp. 174-191.

[28] S. Demir, An Evaluation of Oral Language: The Relationship between Listening, Speaking and Self-efficacy, 2017, pp. 1457-1467. DOI: https://doi.org/10.13189/ujer.2017.050903

[29] M, Rahimi, S, Abedi, The Relationship between Listening Self-efficacy and Metacognitive Awareness of Listening Strategies, Procedia Social and Behavioral Sciences, 2014, 1454-1460. DOI: https://doi.org/10.1016/j.sbspro.2014.03.565

[30] P. B Bullen, How to choose a sample size (for the statistically challenged), 2014.

[31] M. Marzec-Stawiarska Causes and Symptoms of Foreign Language Listening Anxiety: A Case Study of Proficient Students About to Graduate With An Ma in Teaching EFL, 2013.

[32] M. E, Ehrman, Understanding second language learning difficulties, California, SAGE Publications, 1996. 